\title{
IKT, ABL og Jesus Kristus...
}

Gina Bay , Bibliotekar DB

Syddansk Universitetsbibliotek

ginabay@bib.sdu.dk

www.bib.sdu.dk

Jens Dam, Bibliotekar DB

Syddansk Universitetsbibliotek

jensdam@bib.sdu.dk

www.bib.sdu.dk
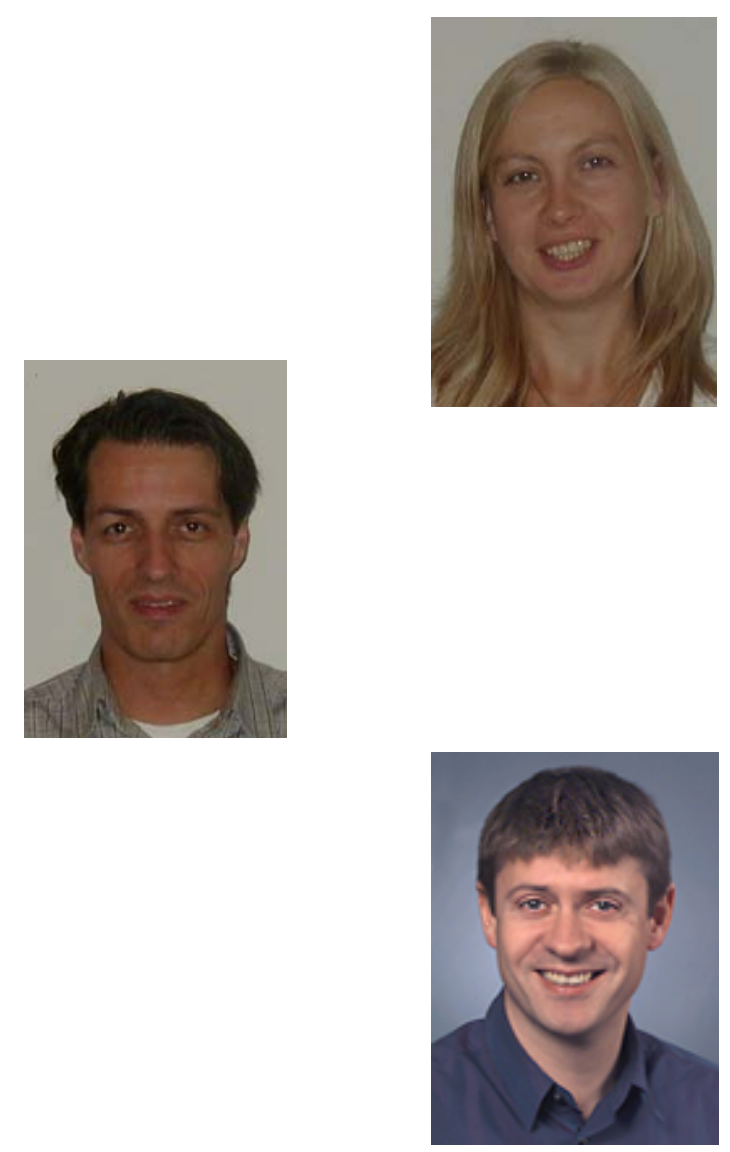

Povl Götke, lic. theol. (ph.d)

Syddansk Universitet

mailto:povlgotke@filos.sdu.dk

www.sdu.dk

Gina Bay og Jens Dam er begge ansat ved Syddansk Universitetsbibliotek. De sidder i betjeningsgruppen for humaniora og har udover almindelig publikumsbetjening undervisningen af studerende og undervisere, e-læring og ophavsret som nogle af deres hovedarbejdsområder.

Povl Götke er lektor ved Institut for Filosofi og Religionsstudier og har i den forbindelse primcert ansvar for forskning og undervisning i Kristendom. Desuden er Götke leder af Center for Universitetspæedagogik, som bl.a. tager sig af adjunktpædagogikum ved Syddansk Universitet.

I forårssemesteret 2004 gennemførte vi i fællesskab et undervisningsforløb i kristendom for grundfagsstuderende på Institut for Filosofi og Religionsstudier, Syddansk Universitet. Forløbet havde en eksperimenterende karakter i både pædagogisk og didaktisk henseende. For det første var der tale om en form for kompetencedifferentieret "teamteaching”, for det andet var forløbet baseret på ABL, altså ”Ability Based Learning” (i.e. kompetence- eller færdighedsbaseret læring), og for det tredje indgik e-læring og IKT - i form af Blackboard og elektronisk informationssøgning - som bærende elementer.

I det følgende vil vi forsøge at beskrive forløbet, tankerne bag det og vores erfaringer som undervisere i forbindelse med den faktiske gennemførelse. Vi håber, at vi ad den vej kan 
"videndele" og inspirere andre til at prøve noget lignende. Fordelen ved det beskrevne koncept er, at det nemt lader sig "oversætte” og implementere i enhver form for undervisning inden for et hvilket som helst fagområde. Det er ikke bare kompatibelt, det er også muligt at håndtere i forskellige skalaforhold. Man behøver med andre ord ikke at få alle sine kolleger til at konvertere til dette paradigme, før det kan føres ud i livet. Det eneste, det kræver, er blot lidt fantasi, en eller flere frimodige samarbejdspartnere og et fleksibelt studienævn.

\section{Konceptet}

Enhver, der har prøvet det, ved hvor stimulerende det er at undervise sammen med andre. Normalt er disse andre lærerkolleger, mennesker, der har det samme at byde på, nemlig viden, måske en lidt anden viden, men viden. Pointen med den slags undervisning er som oftest en rationaliseringsgevinst ved, at man ”moduliserer” forløbet: ”Du gennemgår ditten, og jeg gennemgår datten. Ok?”

Det forløb, vi gennemførte i foråret, var også en form for "teamteaching”, men i stedet for at differentiere teamet efter viden blev det differentieret efter kompetencer. Den ene stod for det rent vidensmæssige (in casu: Kristendom på den globale scene anno 2004) - og var den overordnet fagligt ansvarlige i forhold til studieordning og studienævn -, mens de to andre tog ansvaret for henholdsvis Blackboard og elektronisk litteratursøgning (se nedenfor). Fordelen ved denne type differentiering af teamet er, at der ikke bare bliver tale om en aflastning (det er det også!), men også om en mere organisk, udfordrende og forpligtende form for arbejdsfællesskab, hvor man ikke kan undgå løbende at forholde sig til, reflektere over, diskutere og videreudvikle på selve formen, altså de pædagogiske og didaktiske aspekter.

I dette forløb, hvor to af teamets deltagere var rekrutteret fra universitetsbiblioteket på Syddansk Universitet, var der mulighed for at flytte den viden og alle de informationssøgningsressourcer, der er bundet op i et bibliotek og dets personale, ud i "marken", ud til de studerende, som fik support i forbindelse med opgaveskrivning. Netop et intensiveret samarbejde mellem på den ene side de enheder, der står for uddannelse og undervisning, og på den anden side biblioteksfunktionen indeholder et enormt udviklingspotentiale. Det beskrives på udmærket vis i den rapport, som rektorkollegiets biblioteksudvalg udgav i januar 2003, ”Viden til tiden. Strategisk perspektiv for danske universitetsbiblioteker”.

Det grundlæggende koncept for forløbet var ”Ability Based Learning”, altså kompetenceeller færdighedsbaseret læring. Konceptet bruges for eksempel på Alverno College i USA og på universitetet i Uppsala. Idéen er kort sagt, at videnstilegnelse sker samtidig med kompetenceudvikling og omvendt. Når det koncept er blevet valgt skyldes det for det første, at læring forudsætter aktivitet hos den lærende. Det er vel at mærke for at styrke fag og faglig viden hos de studerende, at vi valgte en færdighedsbaseret læringsmodel! For det andet er der i øjeblikket både fra politisk side og fra aftagerinstitutionerne generelt et ønske om en større grad af gennemsigtighed med hensyn til den reelle viden og de faktiske kompetencer, som de respektive uddannelser formidler til de studerende. Og det gør i sagens natur ikke et koncept som ABL mindre attraktivt.

Nu kan man jo beskrive kompetencer og færdigheder på mange måde og mere eller mindre detailleret og fagspecifikt. Eftersom der var tale om studerende på første år af deres uddannelse, valgte vi at fokusere på nogle helt overordnede og generelle studiemæssige færdigheder: elektronisk informationssøgning på forskellige niveauer, akademisk opgaveskrivning, mundtlig fremlæggelse, feltarbejde og evnen til på kooperativ basis at løse givne opgaver.

I forbindelse med det evalueringsskema, der blev udarbejdet til forløbet, blev der naturligvis taget særligt hensyn til disse videns- og kompetencemål, som var klart defineret fra 
begyndelse af og blev sammenfattet på et uofficielt kursusbevis, som afslutningsvis blev udleveret til de studerende. Både evalueringsskema og kursusbevis har vi vedlagt som bilag.

\section{Bibliotekets ressourcer og elektronisk informationssøgning}

Bibliotekets rolle i forløbet har primært været at vejlede de studerende til at blive kompetente brugere af et elektronisk baseret universitetsbibliotek. I biblioteksverdenen har man gennem de sidste år arbejdet med begrebet ”informationskompetence”, som bl.a. dækker over:

- $\quad$ At man kan arbejde målrettet med at indsamle, udvælge og bearbejde relevante informationer i en konkret situation.

Informations- og kommunikationsteknologien har medført en friere adgang til alverdens informationskilder for nutidens studerende. De studerende har uafhængigt af tid og sted fri adgang til at opsøge opdaterede forskningsbaserede informationer via de vidensressourcer som f.eks. universitetsbibliotekerne stiller til rådighed. Men gør de studerende så det? Eller er mængden af informationskilder så uoverskuelig, at man går direkte til Google, hvor man nemt og hurtigt får svar på hvad som helst? Google er faktisk et fantastisk redskab til hurtigt at finde websider på nettet, men Google finder kun en brøkdel af de websider, der er "derude", og indholdet er mildest talt ikke altid lige videnskabeligt.

Universitetsbibliotekerne forsøger at udvælge og strukturere de bedste vidensressourcer inden for de enkelte fagområder. Det være sig i trykt såvel som i elektronisk form. Og ét af målene i det foreliggende projekt har været at vejlede de studerende i, hvilke kilder der er mest hensigtsmæssige at bruge i en given situation. De studerende er derfor blevet præsenteret for en række redskaber til at finde videnskabelig litteratur, bl.a. litteratursøgning i de videnskabelige databaser som biblioteket stiller til rådighed, men også via gode gamle trykte opslagsværker, hvor man hurtigt og systematisk kan skaffe sig et overblik over et begreb eller et emne.

I dette forløb har vi således koncentreret os om, at de studerende fik en fornemmelse for, hvor de kunne skaffe sig en hurtig, foreløbig viden om et givent emne, og en idé om, hvordan de så kan begive sig ind i en mere dybdeborende research og litteratursøgning via søgninger i videnskabelige databaser.

Det overordnede mål har været at styrke de studerendes kompetencer i det metodiske arbejde med at tilegne sig viden, så de, uanset hvilken situation de står i, har nogle redskaber, der kan bruges på en systematisk og hensigtsmæssig måde. Indgangsvinklen har været, at de studerende lærer at forholde sig pragmatisk til opgaveskrivning. At de får et praktisk blik på, hvordan de helt konkret kan gribe opgaven an, hvilke krav, der skal indfries, og hvad de realistisk kan nå inden for en given tidsramme.

Desværre er opgaveprocessen jo sjældent så lineær og logisk stringent en proces, som man kunne ønske sig. Ting tager tid, og kan man nu nå at få den der helt rigtige artikel hjem fra Spanien eller skal man finde en anden vinkel på opgaven. Der er mange faktorer, der spiller ind under processen - og hvis man så oven i købet skal få det til at fungere i et gruppearbejde, så kan tiden hurtigt gå.

Da der er lagt vægt på, at det er en proces at indsamle og bearbejde informationer, har biblioteket været tilknyttet gennem hele forløbet, så de studerende til enhver tid har kunnet søge støtte alt efter, hvornår de enkelte grupper havde brug for det. Teamet har også gennem hele forløbet haft tæt indbyrdes kontakt og har kunnet diskutere og reagere på de frustrationer, som de studerende har givet udtryk for. I kraft af at være et team har vi haft større mulighed for at gå ind med hver vores styrker og støtte de studerende i de forskellige faser i forløbet. 


\section{Hvad har vi så gjort?}

Via e-læringsplatformen Blackboard blev der oprettet en integreret kursusside, der samlede undervisningsmaterialer, kilder til informationssøgning og de studerendes noter etc. Som optakt til gruppearbejdet med den stillede opgave har de studerende besvaret tematiske småopgaver, hvor det har været formålet, at de forholdsvis hurtigt skulle tilegne sig en overordnet viden om et emne eller et begreb. De studerende har lagt deres svar ud på Blackboard, hvorefter vi har taget en snak om besvarelserne og kildebehandlingen.

Første opgave gik ud på at sammenligne to leksikale opslag på "kristendom", hvilket de fleste løste tilfredsstillende. Næste opgave gik på at klarlægge begreberne "modernitet” og "globalisering". Her var der en del af de studerende, der havde brugt Google og havde plukket lidt hist og pist fra de første par "hits”, som Google rankede. Vi samlede op på denne arbejdsform og trak en linie tilbage til den forrige opgave om opslagsværker. Det blev understreget, at leksika, encyklopædier og andre opslagsværker har den force, at de er baseret på videnskabeligt materiale og forholdsvis hurtigt og smertefrit giver én et overblik. Dette lod til i en vis grad at slå igennem i den følgende opgave, hvor de fleste havde benyttet sig af håndbøger til at beskrive katolsk, protestantisk og ortodoks kristendom.

Efter disse indledende øvelser blev de studerende inddelt i grupper, de fleste 2-mands, enkelte 3-mands, som hver især fik tildelt en bunden opgave, de skulle arbejde med. De studerende fik herefter nogle dage til at orientere sig ift. samarbejdspartner og emne. Efterfølgende blev de introduceret til akademisk opgaveskrivning, hvor forudsætninger og krav blev præsenteret. Parallelt hermed blev de introduceret til målrettet litteratursøgning i forbindelse med deres gruppe-opgaver, og de fik mulighed for at få intensiv og individualiseret vejledning i at indsamle relevante informationer og litteratur.

I den efterfølgende uge tog vi fat på det at udforme hensigtsmæssige søgestrategier og arbejdet med at omforme et givent emne til en problemstilling. Til at understøtte processen blev de studerende gjort opmærksomme på diverse ”webtutorials” til opgaveskrivning og litteratursøgning.

At opgaveskrivning ofte er præget af kaos og usikkerhed blev bekræftet af de studerende. Direkte adspurgt om, hvordan de havde oplevet at få tildelt et tilfældigt emne og derfra skulle fremstille en problemformulering, var det ord som fortvivlelse, usikkerhed, forvirring og frustration, der var fremtrædende. Dette bekræfter en undersøgelse foretaget af den amerikanske bibliotekar Carol C. Kuhlthau (Seeking meaning: a process approach to library and information services. London 1993). Gennem dagbogsoptegnelser og interviews med en række "high school seniors" har hun identificeret seks faser i en model for informationsøgnings-processen i forhold til projekt- og opgaveskrivning:

- Opgaven tildeles

- Indledende overvejelser omkring afgrænsning og tilgangsvinkel

- Afsøge informationskilder på et overordnet plan for at finde et fokus på opgaven

- Valg af fokus for opgaven og problemformulering

- Informationssøgning og -indsamling

- Afslutning og præsentation

Kuhlthau fandt også frem til, at de forskellige faser i opgaveskrivningen er forbundet med store udsving på det følelsesmæssige plan - gående fra usikkerhed, desperation over klarhedsfornemmelse til lettelse og tilfredsstillelse. Pointen hos Kuhlthau er, at det er en yderst vanskelig proces at nå frem til det endelige fokus for opgaven. Det er en fase, som er præget af en stor og til tider overvældende usikkerhedsfølelse, og de studerende har i denne 
fase størst brug for støtte. Den støtte kan de få fra vejlederen, men også en bibliotekar kan i denne fase være behjælpelig med at finde frem til de informationskilder, der forhåbentlig kan bringe de studerende videre i processen med at finde fokus for opgaven. Når først fokus er fundet, indfinder der sig en fornemmelse af klarhed, og der kan arbejdes målrettet med opgaven.

Det blev til fulde bekræftet i forbindelse med vores forløb, at overordentlig mange studerende har endog meget svært ved at konvertere et givent emne til en decideret problemstilling, som der kan arbejdes systematisk med. Oven i dét oplevede flere frustrationer, når de så ikke kunne finde litteratur, der kunne dække den problemstilling, de havde arbejdet så hårdt på at nå frem til. Mange havde kort sagt vanskeligheder med at tænke søge- og tilegnelsesprocessen sammen: At man ikke kan udforme en god problemformulering uden at vide noget om emnet. Og at man til gengæld heller ikke bare kan lancere en god problemformulering uden at vide, om man kan finde kilder, der kan hjælpe én til at belyse problemstillingen på en tilfredsstillende måde. Den tætte sammenhæng mellem afdækningen af litteraturen inden for et emneområde og dét at opstille en god problemformulering må understreges: Ingen af delene kan stå alene!

Langt de fleste af de studerende har bekræftet, at metoden med at orientere sig i håndbøger og netsider har fungeret som hurtig information til at komme videre med mere dybdegående informationssøgning. Som én af dem sagde i et efterfølgende interview: ”Jeg er blevet bedre til at bruge opslagsvœerker for at opnå hurtig viden på et overordnet plan."

Ligeledes har flere opnået en fornemmelse for, at det tager tid at arbejde med litteratursøgningen, og at det ikke nødvendigvis kan overstås med en enkelt hurtig søgning. Som en anden studerende formulerede det: "Jeg godtager ikke bare den første søgning med det samme som jeg nok var tilbøjelig til før."

\section{Blackboard som e-læringsplatform}

Ved SDU hedder den officielle e-læringsplatform Blackboard 6.1. Beslutningen om at købe denne platform blev truffet af SDU's e-læringsstrategiudvalg i 2003 efter længere tids overvejelser og en sammenligning med flere lignende systemer, bl.a. Fronter. En af grundene til at valget lige faldt på Blackboard har ganske givet været, at SDU allerede benytter dette produkt, i en noget ældre version, og at overgangen til et nyt system derfor ville blive betydelig mere smertefri, idet den nye udgave designmæssig ligner den gamle. Indtil sommeren 2004 var det den ældre udgave der var i brug, og det var den der dannede grundlaget for IKT-siden af vores e-læringsprojekt. Denne ”Basis version 5.51” havde et anbefalet brugerantal på 3000 studerende og var en noget mere skrabet version end den, der nu er blevet indkøbt, og som her i efteråret 2004 er ved at blive implementeret og promoveret til underviserne ved SDU. Til forskel fra den ældre version har den nye en række features, som skal gøre tilværelsen lettere for både de studerende, underviserne og systemadministratorerne. Systemet er i stand til at håndtere langt flere brugere, og er i det hele taget blevet opgraderet på de fleste områder. Den enkelte underviser har fået bestemmelse over en række designmæssige faktorer, som i det gamle system var bestemt på forhånd, bl.a. hvor mange "knapper”, der skal være i menulinien, og hvad de skal hedde. Der er desuden købt et tillægsmodul, et "content-system”, der bruges til håndtering og deling af filer. Det betyder, at en underviser, der bruger den samme fil på flere forskellige kurser, kun behøver at have den liggende ét sted, som han så kan linke til fra de enkelte kurser. I den ældre udgave skulle underviseren huske at opdatere filen for hvert sted den lå, når der blev foretaget ændringer.

En anden mulighed i "content-systemet” er, at flere studerende kan være fælles om en fil og kan skrive på den sammen. "Content-systemet” indeholder desuden en virtuel diskplads og en 
e-portefølje, som kan følge den studerende gennem hele studietiden, og som kan nås fra alle steder med internetadgang. Også af gæster, hvis det skulle være ønsket.

En stor del af de ændringer, der er i det nye system, kan dog ikke ses eller mærkes af slutbrugerne, men vil forhåbentlig fører til en hurtigere service fra administratorsiden.

Blackboard kan håndtere de fleste filformater, men som et resultat af den ældre versions mangler er der skudt flere andre hjemmedesignede systemer op ved SDU, som IKT-kyndige undervisere selv har designet. Enten fordi de ikke har været tilfredse med ydelsen i den gamle udgave af Blackboard eller simpelthen fordi, de synes den slags er morsomt. De sidstnævnte vil nok blive ved med at lave deres egne små systemer, men forhåbningen er, at de øvrige undervisere med indførelsen af og undervisningen i mulighederne i det nye system også vil begynde at bruge det.

Blackboard er et underviser- og administratorstyret system, hvilket vil sige, at det er den enkelte underviser, der bestemmer, hvem der skal have adgang til de enkelte kurser, og hvordan strukturen på kurset skal se ud. Underviseren kan dog give skriveadgang til forskellige dele af systemet, ligesom de studerende kan benytte de forskellige kommunikationsmuligheder, der er i systemet. Der er dels en direkte chatfunktion, dels et virtuelt klasseværelse og endelig en email-funktion. Det virtuelle klasseværelse skønnede vi, at der ikke var brug for i vores undervisningsforløb, fordi vi rent fysisk var sammen med de studerende to gange om ugen og desuden også stod til deres rådighed indenfor almindelig kontortid.

Undervisningsforløbet har, udover at være et pædagogisk-didaktisk projekt, der skulle give de studerende visse rent faglige og kompetencemæssige evner, også været rettet mod os selv som undervisere. Vi har, internt i teamet, skullet finde en samarbejdsform, der var hensigtsmæssig, og vi har skullet lære at bruge Blackboard. Vi har måttet gennemtænke strukturen i hele undervisningsforløbet med henblik på, hvor og hvordan de enkelte sider eller filer mest hensigtsmæssigt kunne lægges.

En del af strukturen gav sig selv. De umiddelbare informationer om kurset og praktiske oplysninger om lokaler, studieture etc. til de studerende blev lagt på velkomstsiden, mens de studerendes forskellige gruppebesvarelser blev lagt dybere ind i systemet.

De studerende fik deres små ugeopgaver igennem Blackboard, og de skulle lægge deres stikord og forskellige definitioner af faglige kernebegreber ind, så de øvrige på holdet kunne se dem. Én af ideerne med dette har været at skabe et læringsrum, som de studerende følte et større ejerskab overfor, og som de siden hen kan bruge som en slags vidensdatabase gennem hele deres uddannelse.

Kommunikationsmæssigt blev de studerende opfordret til at benytte sig af de faciliteter, der er i Blackboard, henholdsvis almindelige mailinglister og "discussion boards" for de enkelte grupper. Deres besvarelser og diskussioner skulle lægges ind i "discussion board”, så hele holdet kunne få glæde af en successiv vidensakkumulation.

Vi havde også håbet, at de enkelte grupper ville benytte sig af kommunikationsmulighederne, men det viste sig efterfølgende at flere af dem brugte messenger, dels fordi de i forvejen er fortrolige med det system, dels fordi messenger selv gør opmærksom på, når der er en ny besked, i modsætning til Blackboard, hvor den studerende hele tiden skal logge ind for at tjekke, om der er nogle nye beskeder.

I en interviewundersøgelse med flere af grupperne, blev de spurgt om, hvordan de oplever at skulle bruge Blackboard. Flere svarer, at noget af det bedste ved Blackboard er, at man uanset tid og sted nemt kan hente og tjekke informationer fra undervisere.

Med hensyn til at lægge skriftlige besvarelser ud på Blackboard, så de øvrige på holdet kan se dem, er der noget modstridende følelser. Dels ønsker de studerende stor åbenhed og så meget information som muligt, men på den anden side bryder de sig ikke om at skulle lægge deres 
notater ud til fri beskuelse. Det skyldes ikke ejerskabsfornemmelser, men nok snarere blufærdighed.

Flere studerende udtrykte irritation over, at man ikke kan se om de indlæg, man har lavet, er blevet læst, og man kan ikke se, om der er andre, der er online samtidig med én selv. Dette resulterede som nævnt i, at de studerende brugte de kommunikationsværktøjer de allerede kendte i forvejen, så som almindelig mail, telefon og messenger.

En vigtig forudsætning og motivationsfaktor for at få studerende til at benytte sig af et system er, at de kun skal logge på ét sted for at få al den information, de har brug for. Om den nye udgave af Blackboard enten kan implementere de øvrige sites, de studerende allerede har, eller om Blackboard kan implementeres i den almindelig studenterportal, skal vi ikke kunne sige, men et samspil må nødvendigvis finde sted, hvis et e-læringssystem skal blive en levende og voksende succes og ikke bare en meget dyr og besværlig udgave af et postsystem. Som det er nu, skal den studerende først logge ind på studenterportalen og dernæst bevæge sig videre derfra med yderligere indlogninger alt afhængig af, om han eller hun vil tjekke sin mail eller se, om der er nye beskeder fra en underviser i Blackboard. Selvom Blackboard med den nye version er blevet forbedret, er risikoen stadig at disse forskellige service-systemer bliver et irritationsmoment i stedet for en lettelse, fordi der i højere grad er tale om "parallelsystemer" end der er tale om en platform.

\section{Ophavsretslige problemer}

Når et undervisningsforløb planlægges, sørger den enkelte underviser normalt for, at der bliver lavet et kompendium, eller at der er en litteraturliste, der bliver undervist efter. Flere undervisere benytter sig også af muligheden for at oprette semesterlånshylder på biblioteket, hvor de værker, der bruges i undervisningen, bliver låst fast og kun kan benyttes på bibliotekets læsesal. Med henblik på fotokopier i kompendier og handouts, indgår SDU på lige fod med de fleste andre uddannelsesinstitutioner her i landet i den rammeaftale, der er indgået med CopyDan. Denne aftale gør, at underviseren kan fotokopiere alt materiale, så længe han overholder visse procentsatser og indrapporterer, hvad der er blevet kopieret. I en e-læringssammenhæng vil det naturlige være at digitalisere disse materialer og lægge dem til de studerende i elektronisk form. En del af materialerne er allerede digitaliserede. Biblioteket har licens til et stort antal tidsskrifter i elektronisk form, og mange af disse må benyttes i såkaldte studiesamlinger. Andre må der laves dybe links til, mens en mindre del ikke tillader hverken studiesamlinger eller dybe links. Disse kan der dog stadig linkes til, men den studerende må selv browse eller søge den specifikke artikel fra tidsskriftsudbyderens hovedside. Biblioteket har ligeledes et mindre antal e-bøger som kan bruges i elæringssammenhæng. Disse ovennævnte materialer dækker dog langtfra, hvad den enkelte underviser må ønske at bruge til sine studerende.

I en e-læringssammenhæng kan underviseren altså fortsætte som om der var tale om almindelig undervisning og benytte sig af kompendier, handouts, litteraturlister og semesterlån. Underviseren kan også vælge at undersøge hvert enkelt dokument for dels at finde ud af, om det findes elektronisk, dels hvordan det i givet fald må bruges. Hvis materialet ikke allerede eksisterer i digitaliseret format, kan underviseren selv digitalisere det, men må dernæst søge den enkelte ophavsmand om tilladelse til at benytte det. Med en almindelig litteraturliste på bare 20 tekster til et enkelt semester, kan det godt gå hen og blive en temmelig uoverskuelig opgave for den enkelte underviser at skulle give sig ud i kontraktforhandlinger med flere forskellige forlag. Ved SDU kan underviserne få hjælp dels igennem en elektronisk ophavsretsmanual, dels ved at kontakte biblioteket, der tilbyder hjælp til at opnå enkelttilladelser. Men det tager tid, og det koster penge, så i realiteten er det ikke en option. 


\section{Afsluttende betragtninger}

Der har i pressen igennem de sidste par uger stået en del blæst om en undersøgelse, som lektor Gorm Harste på Århus Universitet har lavet. Af den fremgår det, at de studerende i dag ikke har nævneværdig paratviden på det, man kunne kalde for klassisk almendannelse. Resultatet kommer ikke bag på forfatterne til denne artikel, for vi indledte semesteret med at præsentere de studerende for en spørgeskemaundersøgelse med ca. 150 spørgsmål inden for almendannelse. Foruden dette spurgte vi også til deres forudsætninger, når det kom til elæring. Som det fremgår af bl.a. Lars Kaysers artikel i dette tidsskrift, er det nemlig væsentligt at finde ud af, hvor de studerende står rent ressourcemæssigt: Er de fortrolige med at bruge computer og internet? Har de adgang til internettet fra deres privatadresse? Kender de til elæringsplatformen, her Blackboard? Etc., etc.

Imidlertid gælder det både med hensyn til de studerendes paratvidensniveau og deres "paratkunnensniveau", at nok er det af indlysende grunde vigtig at kende til det med hensyn til, hvor man skal sætte ind eller hvad man må tage hensyn til, når man designer et kursusforløb. Men det, det ellers handler om, er jo "slutproduktet”, og det fokuserer man ikke så meget på. Eller sagt med andre ord: Vi er på universiteterne meget optaget af, hvad de gymnasiale uddannelser leverer til os, men vi glemmer at se på, hvilke resultater vi selv opnår med de studerende, altså hvilket videns- og hvilket kompetenceniveau, de har, når vi sender dem videre ud i verden. Og meget tyder på, at det er for lavt, både i den ene og den anden henseende. Det er grunden til at bruge aktiverende undervisningsformer som ABL, PBL, CBL, DBL og hvad de nu ellers har af navne.

Vores erfaringer med undervisningsforløbet i foråret er, at man faktisk godt kan få de studerende til at bruge Blackboard, selv om de ikke i forvejen er fortrolige med IKT. Det handler blot om at gøre det til en integreret faktor i forløbet. Integration kommer imidlertid først i stand, når den specifikke kompetence, nemlig brugen og bemestringen af IKT, bliver en del af selve eksamensgrundlaget!

Hvis man skal køre et forløb som det beskrevne, er det som nævnt i indledningen nødvendigt med et fleksibelt studienævn. Eftersom eksamen er den suverænt mest adfærdsbestemmende faktor, er det for eksempel meningsløst at fastholde en traditionel eksamensform, og det vil jo sige en enten mundtlig eller skriftlig eksamen af summativ karakter, altså som afslutning. Sådanne eksamensformer kan ikke bruges, når man ønsker at motivere de studerende til at udvise en jævn aktivitet og medvirke seriøst ved de aktiviteter, der fordeler sig over hele semesteret. Man kan kun få de studerende til for alvor at bruge tid og ressourcer på sådan noget som feltarbejde, informationssøgning og opgaveskrivning, Blackboard, mundtlige oplæg etc., hvis det er en del af eksamensgrundlaget.

Vi gjorde det i praksis på den måde, at vi tilbød de studerende to modeller: enten den traditionelle, hvor de alene blev bedømt på en skriftlig opgave, eller den alternative, hvor de foruden opgaven også blev bedømt på deres engagement i øvrigt. Man kan sige, at trykket blev fordelt på en større overflade. 30 ud af 40 studerende valgte den sidstnævnte, som bl.a. betød, at de måtte affinde sig med mødepligt gennem hele semesteret og til alle aktiviteterne, også feltarbejde og ekskursion til København.

Det kan ikke understreges nok, hvor vigtigt det er at rette eksamensformen ind efter konceptet, og det vil i det foreliggende tilfælde sige at gøre den formativ. Hvis man kører konceptet, ABL, men i øvrigt fastholder en traditionel, summativ eksamensform, er det dømt til at mislykkes, fordi de studerende ikke kan motiveres til at yde deres del. Og hele konceptet handler ganske enkelt om at forskyde fokus fra underviseres forvaltning af faget til de studerendes forvaltning.

Vi har nævnt forskellige gevinster i forbindelse med IKT og e-læring i undervisning, fortrinsvis af pædagogisk og didaktisk karakter og med hensyn til at opnå en synergieffekt 
mellem institutioner som eksempelvis bibliotek og uddannelsesenhed. Der kunne nævnes andre. Her skal blot antydes to af de tungtvejende. Brugen af en frelles platform mellem undervisere og de studerende giver for det første mulighed for en større integration af undervisning og forskning - og dermed for egentlig forskningsbaseret undervisning. For det andet bliver der med den kooperative opbygning af en fælles "bank” med oplysninger og informationer, litteraturhenvisninger og opgaveforslag, definitioner og oplæg, modeller og materiale i øvrigt, tale om en stadigt voksende, fagspecifik videns- og kompetenceplatform, som givetvis vil få permanent karakter. Efterhånden bliver denne platform et uudtømmeligt og uvurderligt skatkammer med alt til det enkelte fag henhørende, både set fra undervisers og studerendes side, hvad enten det gælder almindelig undervisning, vejledning i forbindelse med opgaveskrivning eller arbejde med faget i almindelighed, herunder forskning.

Og dermed ender vi i en ophavsretlig problematik, for hvem tilhører denne databank egentlig, når alt kommer til alt: Er det underviserens eller undervisernes? Er det de studerendes bank, de har jo spillet en aktiv rolle mht. at generere den? Eller er den rette ejer institutionen, in casu: Syddansk Universitet? Eller tilhører materialet Blackboard?

Som bilag har vi hæftet dels det skema, som blev udviklet til den afsluttende evaluering af forløbet, dels det uofficielle kursusbevis, som blev udleveret til sidst. Vi vil lige knytte et par kommentarer til bilagene.

Sammen med en mundtlig samtale udgjorde evalueringsskemaet fundamentet for den sammenfattende indstilling, som gik videre til studienævnet. Det man kan konstatere er, at evalueringen overvejende handler om alle de konkrete elementer, der indgik i forløbet, og at den fokuserer på de studerendes indsats. På den måde er denne evalueringsproces efter vores mening mindre intimiderende og mere konstruktiv end sådan nogle sædvanligvis er. Eksempelvis har de studerende ingen forudsætninger for at udtale sig om underviserens faglige kompetence og bør derfor ikke spørges om den.

Med hensyn til det uofficielle kursusbevis er det som nævnt nogle helt overordnede studiemæssige kompetencer, vi har fokuseret på, eftersom der er tale om studerende på første år af deres respektive uddannelser. Jo længere frem i forløbet, man kommer, og jo mere de studerende er kommet ind i faget, jo mere kan man specificere den viden og de kompetencer, der er målet for kurset.

Det foreliggende kursusbevis skal naturligvis blot opfattes som et første og foreløbigt udspil. Det er klart, at lige præcis på dette område, nemlig sikring af og dokumentation for den tilegnede viden og de erhvervede kompetencer, kræves der et intensivt arbejde, som skal forankres institutionelt. 


\title{
Bilag 1
}

\author{
Evaluering \\ Kristne Religioner I \\ Kristendom på den globale scene \\ Fagligt ansvarlig Povl Götke \\ Foråret 2004 \\ Center for Religionsstudier \\ Syddansk Universitet
}

(NB! Brug også bagsiden af papiret, hvis det er nødvendigt!!!)

\section{Feltarbejde}

Hvordan bedømmer du udbyttet af feltarbejdet?

Var fire besøg for lidt eller for meget?

Følte du dig godt nok forberedt med baggrundsviden og interviewguide?

\section{Skriftlig opgave}

Foretrækker du at vælge opgave selv frem for at få den stillet (fri/bunden)?

Arbejder du helst på egen hånd eller sammen med andre?

Hvordan har du oplevet at få tildelt samarbejdspartner?

Fik du noget ud af at arbejde med opgaven (viden/kompetencer)?

Nævn en vigtig erfaring, som du tager med dig til næste opgaveskrivning..

\section{Mundtlig fremleggelse}

Fik du noget ud af at skulle holde oplæg for de andre studerende?

Fik du noget ud af at høre på de andre studerendes oplæg?

Hvad vil du gøre anderledes næste gang du skal holde oplæg?

Informations- og litteratursøgning

Har kurset betydet en forandring af din måde at søge informationer på?

Hvis ja, hvordan?

Føler du at kurset har gjort dig bedre i stand til at vurdere pålideligheden af informationer?

\section{Blackboard}

Hvor ofte har du været på Bb i gennemsnit pr. uge?

Hvad har du mest brugt $\mathrm{Bb}$ til?

Bruger du internettet mere nu, efter at du er blevet introduceret til Bb og elektronisk

litteratursøgning?

Hvis ja, hvordan?

Hvor mange timer er du sådan ca. på nettet om ugen?

Hvad har du brugt internettet til indenfor de sidste to uger (mail, chat, diskussionsgrupper, spil, Bb, infosøgning i faglig sammenhæng/egne interesser, køb/salg og banking, downloading af musik/film, nyheder, andet)?

Kunne du finde på frivilligt at bruge $\mathrm{Bb}$ i anden sammenhæng?

Studietur til København

Fik du noget ud af turen til København?

Hvis ja, hvad? 
Havde du forberedt dig inden?

Hvis ja, hvordan?

Viden og faglig forståelse

Er det din fornemmelse, at din viden om kristendom er blevet større gennem de sidste tre måneder?

Hvis ja, på hvilke område?

Hvad har du lært mest af?

Er der for dig at se sammenhæng mellem kristendom og religionsstudiets andre faglige

discipliner?

Har du været tilfreds med undervisningsformen?

Hvis du selv skulle vælge, ville du hellere have haft et traditionelt undervisningsforløb?

\section{Underviserne}

Er du tilfreds med planlægning og gennemførelse af kurset?

Er du tilfreds med kontakten mellem underviser og studerende?

Er underviseren til at forstå?

Hvordan vurderer du underviserens evne til at sammenholde, sammenfatte og perspektivere faget?

Hvordan vurderer du den støtte, du har fået til brug af Bb?

Hvordan vurderer du den introduktion, du har modtaget til informations- og littaratursøgning?

De studerende

Er du tilfreds med din egen indsats?

Er der noget, du gerne ville have gjort anderledes?

Er du tilfreds med dine medstuderendes indsats?

\section{Evaluering}

Er du tilfreds med den mundtlige og skriftlige midtvejsevaluering?

Føler du at du har haft indflydelse på forløbets indhold og form?

Er slutevalueringsproceduren tilfredsstillende?

Andre kommentarer (fx konkrete forslag til forbedringer, sammenfattende vurdering af forløbet, specielt positive eller negative forhold ved kurset ell. lign.). 


\title{
Bilag 2
}

\section{Uofficielt videns- og kompetencebevis for kursusforløb i Kristendom I}

\author{
Kristne religioner på den globale scene
}

Viden

Gennem kurset har de studerende fået et overordnet kendskab til nogle af de forskellige former for kristendom, som kan findes rundt omkring i verden netop nu. Særligt studeret emne var Jesu Kristi Kirke af Sidste Dages Hellige (mormonerne).

Verden er geografisk blevet opdelt i fire regioner: Amerika'erne, Asien med Mellemøsten, Afrika og Europa med Oceanien. Inden for disse områder er der blevet gået i dybden med ca. 20 specifikke temaer, fem for hver region.

Endvidere er de studerende blevet gjort bekendt med en række "hårde" talmæssige forhold såsom geografisk og konfessionel fordeling af kristne på verdensplan, og de er blevet præsenteret for demografiske tendenser og den sandsynlige betydning for kristendommens udvikling over de næste 50 år.

\section{Kompetencer}

Kurset er planlagt og gennemført med ønsket om maksimal deltageraktivitet. Målsætningen har foruden at formidle den beskrevne viden været at give de studerende en række kompetencer på forskellige områder.

Det gælder først og fremmest indenfor informationssøgning, hvor de studerende har lært at orientere sig i forskellige former for informationskilder fra håndbøger over kataloger til databaser. De studerende er blevet opøvet i evnen til at vurdere relevansen af de nævnte kilder i forhold til en given opgave, og har i den forbindelse også arbejdet med at udforme brugbare søgestrategier.

Med hensyn til kommunikation er de studerende blevet stillet overfor formidlingsopgaver af både skriftlig og mundtlig karakter. Endvidere er det blevet tilstræbt at give de studerende relationskompetencer i den forstand, at de har skullet løse givne opgaver sammen med andre studerende.

Kurset omfattede både forelæsninger, gruppearbejde, feltarbejde i lokalmiljøet og studietur til kristne kultsteder i København. Hele forløbet har teknologisk været understøttet af SDU's konferenceprogram Black-board. Det har været den fælles platform, som undervisere og studerende har brugt til forskellige former for kommunikation og problemløsning.

\section{Bibliotekar Gina Bay $\quad$ Bibliotekar Jens Dam ～Lektor Povl Götke (kursusansvarlig)}

Foråret 2004

Center for Religionsstudier

Syddansk Universitet 